Stanley S. Pliskoff (Editor, 1970-1972)

\title{
UNGERTAIN DAYS-
}

It was a long time ago, especially in terms of personal perspective. Back then, SEAB conducted business at meetings of the Eastern Psychological Association. I suppose that reflected the view held then that the experimental analysis of behavior was an "East-Coast movement."

I don't have to check-EPA was held in Philadelphia in the Spring of 1969, and it was there I was elected Editor. I had just recently come to the University of Maine as Department Chair(man) and was surrounded by a department somewhat suspicious of my intentions, at least so I thought. The headache I developed in Philadelphia after the SEAB meeting was memorable. I don't get headaches often, and that was the worst one before then or since. Aspirin barely touched it.

The Editor's duties were transferred during the Summer and early Fall. Charlie Catania eased the transition; he was (still is) extremely well organized. Manuscripts submitted to Charlie were forwarded to me, but he kept a list of the authors and their addresses. Well,

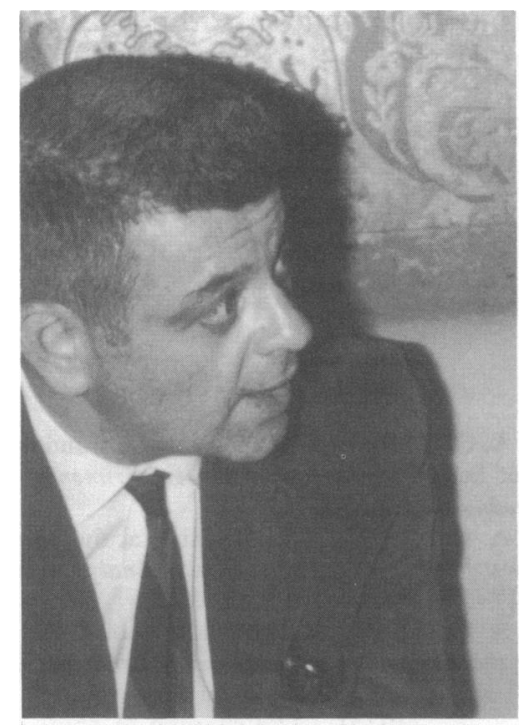

Stanley S. Pliskoff, 1968. one of those manuscripts vanished-it was on the JEAB desk in the evening and gone in the morning. I called Charlie and told him what I remembered of it, the state it came from, as I recall. He gave me the author's name and address. By the way, JEAB did have an office and a secretary right from the start, courtesy of the College and our Dean at the time, John Nolde.

The first issue that identified me as Editor was that of January, 1970. It contained nine research articles, two special ones, and two technical notes. The special articles were by Kenneth MacCorquodale and by J. R. Kantor (nice start). The Executive Editor throughout my term was the ever-reliable Vic Laties, who followed me as Editor and should have the next piece in this sequence. Charlie stayed on as Review Editor. Kay Dinsmoor was the Business Manager, and I have never had to concern myself with any of the business aspects of the journal.

What was my term like? Do you remember May 4, 1970? That day set the tone-it was the day on which four Kent State students were shot dead on campus. That event followed by only a few days the incursion into Cambodia by American and South Vietnamese soldiers. Each morning that I arrived on campus, I didn't know if JEAB was in business that day or week. The Dean's office was occupied, and we lost two days of classes. The SDS storm troopers were not numerous, but they forcefully acted out their democratic inclinations by shouting down speakers with whom they disagreed.

Those years were full of distracting events: the "Chicago Seven" and Charles Manson trials, the Calley court-martial, the first and greatest "—_ gate" of all, etc. As Department Chairman, I was an establishment figure, and there were some difficult times. But JEAB ran smoothly; a lot of the credit was due the Associate Editors during those years: Larry Byrd, Ed Fantino, Lew Gollub, Tony Nevin, Howie Rachlin, Dave Williams, and 
Mike Zeiler. Never a better or more reliable bunch.

Bill Cumming died early that year, and he was remembered in my second issue. That issue also carried Dick Herrnstein's seminal article, "On the Law of Effect."

Quick, how many supplementary monographs did JEAB publish? The answer is five; the last one was published during my term as Editor (but invited by an Editor before me). Unless I missed something, there has not been a monograph supplement since 1970 ! In the issues that bore my name as Editor there were just over 250 research articles published, plus a number of book reviews, technical articles, and notes. I wondered if there was one of the research articles I could identify as my favorite. I scanned the issues, and there was one. I'll not name it though, because I don't need a pack of new enemies!

As I look back to those years, I think I can say that I had fun. From my perspective today, I would do it again then, but never now.

Department of Psychology

University of Maine-Orono

Orono, Maine 04473

Victor G. Laties (Editor, 1973-1976)

\section{DOUBLE DUTY}

John Boren visited Bernie Weiss and me in Rochester in early 1966 . He mentioned that he was looking for nominees to stand for editor to succeed Nate Azrin. Bernie suggested me. The notion struck me as faintly ridiculous. I had come out of a nonoperant background and, although I had been on the JEAB editorial board for about three years by then, had all too frequently been reminded of my own incompetence by the arrival of the other reviewer's comments along with the editor's letter to the author. During a visit to Washington in March, I had dinner with John and he said he wanted to nominate me. The job started to sound less forbidding, the way he described it. A week later there was a letter from John, formally asking me to stand. After a restless night I wrote him suggesting several others that he should approach, but concluding with "if these do not prove to be possible alternatives, then I will be happy to serve as a backstop." But I was lucky; the SEAB Board of Directors wisely chose Charlie Catania. Then Charlie turned around and suggested that I share the job with him; he, as Editor, would actually edit the journal while I served as Executive Editor, taking care of the business and financial aspects. That offer was accepted with delight and I have been involved with such matters ever since.
In the spring of 1972 , after six years as Executive Editor under Charlie and then Stan Pliskoff, I felt more comfortable with the idea of editing JEAB when the possibility arose again. The SEAB meeting was in Boston this time. After my election, I walked down to Newbury Street. There on the sale rack in my favorite store was a blazer in my size-and it was green, JEAB green. I bought it and wore it (with grey slacks) when visiting Stan Pliskoff that summer to find out how he had organized his editorial responsibilities. He never noticed.

During his last year, Stan Pliskoff had used me as a half-time Associate Editor as well as Executive Editor and I got to know and appreciate the work done by his full-timers. I kept on as many as possible and thus started my own term with as strong a group of Associate Editors as has ever been put together. Serving all four years were Larry Byrd, Don Hake, Tony Nevin, and Mike Zeiler, plus Charlie Catania as both Review Editor and part-time Associate Editor. Lew Gollub worked for half the first year and Ed Fantino for the first two years, both leaving in order to take sabbaticals abroad; and Stan Pliskoff, by then well rested from his own term, worked as Associate Editor for 1976. Since all but 